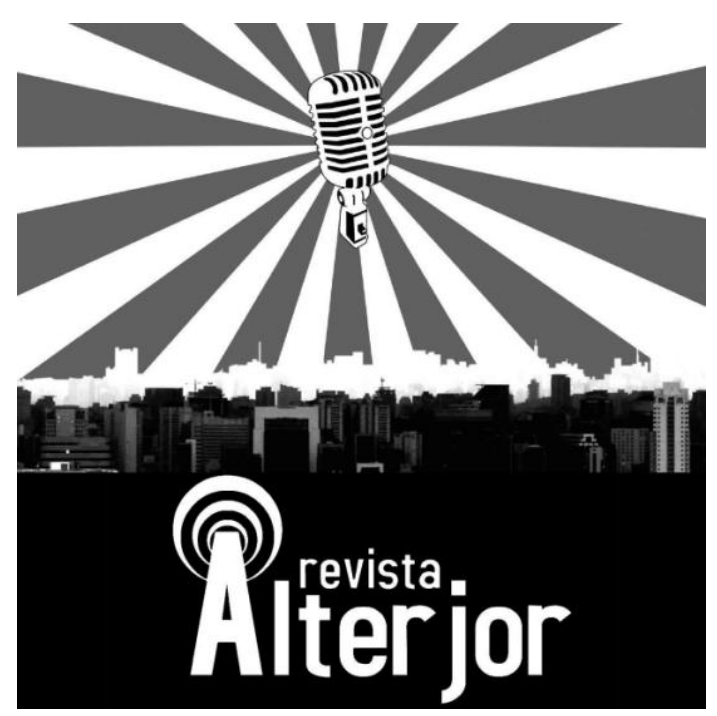

\title{
O ETHOS JORNALÍSTICO NAS CRÔNICAS DE GUERRA DE RUBEM BRAGA
}

\author{
Marcos Paulo da Silva ${ }^{1}$ \\ Caio Mateus Teruel de Paula ${ }^{2}$
}

RESUMO: O artigo constitui uma análise da representação de um ethos jornalístico nas crônicas de guerra do escritor brasileiro Rubem Braga. O recorte empírico remete a quatro textos originalmente publicados no jornal Diário Carioca enquanto o cronista atuava como correspondente junto ao exército brasileiro na Itália durante a Segunda Guerra Mundial. A partir da análise das crônicas, verifica-se a complexidade por trás do ethos efetivo denotado por Rubem Braga como amálgama de um "ethos prédiscursivo", de um "ethos dito" e de um "ethos mostrado" típicos das contradições e das precariedades do contexto em que os textos se inserem.

PALAVRAS-CHAVE: Jornalismo. Literatura. Ethos jornalístico. Crônica. Rubem Braga.

ABSTRACT: This article consists an analysis of the representation of journalistic ethos in the war chronicles by the Brazilian writer Rubem Braga. The corpus refers to four texts originally published in the newspaper Diário Carioca while the writer was a correspondent with the Brazilian army in Italy, during the Second World War. From the chronicles analysis, the complexity behind Rubem Braga's effective ethos is verified as an amalgam of a "pre-discursive ethos" as well as of a "said ethos" and a "shown ethos", typical of the contradictions and precariousness of the context in which the texts are inserted.

KEYWORDS: Journalism; Literature. Journalistic ethos. Chronicle. Rubem Braga.

${ }^{1}$ Professor dos programas de pós-graduação em Comunicação e em Estudos de Linguagens da Universidade Federal de Mato Grosso do Sul (UFMS). Doutor em Comunicação Social pela Universidade

Metodista de São Paulo (Umesp), com estágio de doutorado-sanduíche na Syracuse University (Nova Iorque, Estados Unidos).E-mail: marcos.paulo@ufms.br

${ }^{2}$ Mestrando do Programa de Pós-Graduação em Comunicação e jornalista graduado pela Universidade Federal de Mato Grosso do Sul (UFMS). E-mail: caioterue105@gmail.com

Revista AL TERJOR

Grupo de Estudos Alterjor:Jornalismo Popular e Alternativo (ECA-USP)

Ano 10 Volume 02 Edição 22 Julho-Dezembro de 2020

Avenida Professor Lúcio Martins Rodrig̉ues, 443, Cidade Universitária, São Paulo, CEP: 05508-020 


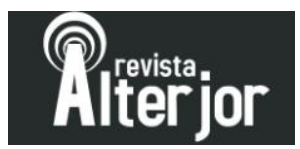

\section{Para situar o debate}

O presente trabalho se propõe a analisar a representação de um eventual ethos jornalístico nas crônicas de guerra do escritor brasileiro Rubem Braga. Três perguntas de fundo concedem corpo à discussão: 1) quais elementos discursivos presentes nos textos do cronista denotam seu vínculo com o campo jornalístico, seus valores e técnicas?; 2) por quais marcações discursivas o autor, nos idos dos anos 1940, invoca um ethos da profissão de jornalista?; e 3) como isso é transpassado de forma implícita e explícita nas crônicas redigidas no seio de um período de exceção? O recorte empírico da análise remete a quatro textos originalmente publicados por Rubem Braga no jornal Diário Carioca enquanto atuava como correspondente junto ao exército brasileiro na Itália, durante a Segunda Guerra Mundial. Para efeitos práticos, vale-se neste estudo do material compilado no livro Crônicas da Guerra na Itália, lançado por Rubem Braga primeiramente em 1945. O livro teve sua edição inicial com o título Com a FEB na Itália, sendo lançado pela segunda vez como Crônicas da Guerra, em 1964, e pela terceira vez com o atual nome, em $1985^{3}$.

A materialidade original dos textos que constituem o corpus desta pesquisa, portanto, remete a um primeiro vínculo entre os campos do jornalismo e da literatura, uma vez que a gênese das crônicas se estabelece nas páginas de um periódico diário para posteriormente constituir-se como obra literário-jornalística no formato de livro. Em termos temporais, a primeira crônica redigida pelo escritor na Itália e enviada por avião ao Rio de Janeiro, data de setembro de 1944, e a última de abril de 1945. Em um vértice analítico, o estudo se volta a quatro crônicas - Um espião; Luminárias; Cartas e Imprensa de trincheira - produzidas entre novembro e dezembro de 1944 que, embora referentes a assuntos distintos, complementam-se na expressão de um ethos discursivo de Braga como jornalista em suas distintas dimensões, quais sejam intersubjetivas ou sociais. Entende-se que as características distintivas para a constituição do recorte empírico residem na própria costura de elementos que denotam discursivamente a aproximação do cronista com o campo jornalístico.

\footnotetext{
${ }^{3}$ Vale-se na análise da sétima edição da obra, datada de 2014.

Revista ALTERJOR

Grupo de Estudos Alterjor:Jornalismo Popular e Alternativo (ECA-USP)

Ano 10 Volume 02 Edição $22 \quad$ Juho- Dezembro de 2020

Avenida Professor Lúcio Martins Rodriģues, 443, Cidade Universitária, São Paulo, CEP: 05508-020
} 


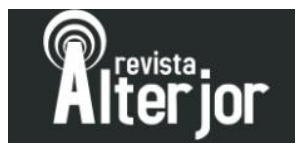

Nesse cenário, por meio do conceito de ethos, noção de origem aristotélica cara ao terreno da análise discursiva, o artigo se debruça sobre a escrita primorosa de Rubem Braga, que nas palavras de Antonio Candido (1992) constitui um cronista por natureza, um "cronista puro". Não por acaso, justamente pelo fato de conseguir projetar - mesmo em um complexo cenário de exceção, das limitações do front da guerra à censura do Estado Novo varguista - um olhar diferente às temáticas e aos fatos da vida cotidiana, a escrita de Rubem Braga, conhecida nacionalmente por sua forma simples e envolvente, rende ao escritor, falecido em 1990, o título ínclito de "narrador sentimental".

\section{A trajetória de Braga: elementos do ethos pré-discursivo}

Nascido em 1913, na cidade de Cachoeiro de Itapemirim, no interior do Espírito Santo, Rubem Braga iniciou seu trabalho no campo jornalístico em 1932, antes mesmo de concluir seus estudos em Direito, ao assinar uma crônica no Diário da Tarde, do Rio de Janeiro. Absorvido pelo jornalismo e trabalhando como comentarista político e repórter, o autor capixaba se tornou um dos mais reverenciados cronistas brasileiros, destacando-se pela simplicidade das palavras e pelo amplo espectro temático que conseguia cobrir a partir de sua narrativa. Nas palavras do crítico literário Antonio Candido (1992: 17), ao abordar o desenvolvimento da crônica brasileira, Rubem Braga ocupa um lugar de destaque:

Acho que foi no decênio de 1930 que a crônica moderna se definiu e consolidou no Brasil, como gênero bem nosso, cultivado por um número crescente de escritores e jornalistas, com os seus rotineiros e os seus mestres. Nos anos 30 se afirmaram Mário de Andrade, Manuel Bandeira, Carlos Drummond de Andrade, e apareceu aquele que de certo modo seria o cronista, voltado de maneira praticamente exclusiva para este gênero: Rubem Braga.

Por meio da crônica, Rubem Braga encontrou sua essência jornalística e trabalhou nela até o fim de sua vida. O escritor seguiu sua carreira em diversas capitais brasileiras, como São Paulo, Recife, Belo Horizonte e Porto Alegre. Em 1944, mudouse para o Rio de Janeiro, onde trabalhou no Diário Carioca e se tornou correspondente na Segunda Guerra Mundial, na Itália. Nesse período, Rubem Braga acompanhou a 


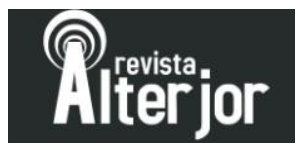

Força Expedicionária Brasileira (FEB) que combateu junto aos aliados em regiões como Lucca e Monte Castello.

Até aportar no Diário Carioca na década de 1940 e tornar-se correspondente na Europa, entretanto, Rubem Braga aos poucos talhou seu estilo no próprio tecido político brasileiro. Do jovem cronista flâneur, que se dedicava a sentimentos, conversas cotidianas e praias, a década de 1930 inaugurou um Rubem Braga político, atento às mudanças da vida urbana do Rio de Janeiro e de todo o país. O escritor vivenciou de perto a ebulição no cenário político nacional que culminou, em 1937, na escalada autoritária e na constituição do Estado Novo varguista, que vigoraria até 1945 - período que envolve a eclosão e o desenrolar da Segunda Guerra Mundial. A ideologia governamental brasileira naquele período calcava-se na tentativa de constituição de um estado coeso, centralizador e nacionalista, ou seja, forjava-se no Brasil uma "nova política" que se sustentou sob o signo do autoritarismo, da censura e do populismo. Tanto é que após a tomada de Monte Castello em 1945, episódio emblemático enfrentado pelos soldados brasileiros ao final da guerra, um jornal editado por militares estadunidenses trouxe à tona o que ocorria no país com a seguinte manchete: "O Brasil mandou soldados para acabar com a ditadura de Hitler e não quer acabar com a ditadura que está instalada em sua casa" (Carvalho, 2013).

Sustentado pela política autoritária do Estado Novo, Getúlio Vargas não permitiu, em um primeiro momento, que jornalistas não associados à Agência Nacional fossem à Itália atuar na cobertura da presença do Brasil no conflito armado. Dessa forma, a primeira saída de repórteres ocorreu em 2 de julho de 1944. Os jornalistas independentes, incluso Rubem Braga, saíram apenas em 22 de setembro do mesmo ano. Ao todo foram cinco: Braga, do Diário Carioca; Egydio Squeff, do O Globo; Raul Brandão, do Correio da Manhã; Joel Silveira, dos Diários Associados, e Thassilo Mitke, da Agência Nacional. Eles viajaram com soldados do segundo e do terceiro escalão.

Marco Antonio de Carvalho (2013) ressalta a característica da formação das tropas brasileiras enviadas à Itália e a influência delas na escrita de Rubem Braga. Tratavam-se, em sua maioria, homens mal treinados, cidadãos médios, "homens do 


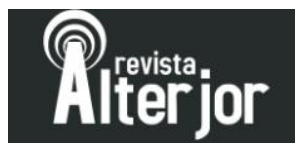

povo", que foram enviados para a guerra sem o aporte necessário seja técnico, físico ou mental. Nesse contexto, o cronista Rubem Braga construiu seus textos, escolhendo personagens majoritariamente simples, sem grandes glórias ou feitorias. Segundo Carvalho (2013: 23-24),

Foi a esses homens que Rubem preferiu acompanhar e ouvir: grande parte das suas reportagens, publicadas no Diário Carioca e, mais tarde, lançadas no livro Com a FEB na Itália - que dedicaria aos 'dois pracinhas do povo', um chofer e um pedreiro, os cachoeirenses Quitito e Orestes, mortos em 1945 -, são conversas com soldados, homens simples do interior do país. Pois estudantes de classe média, exatamente aqueles que lideraram campanhas e passeatas a favor da entrada do Brasil na guerra, não foram convocados para se expor às bombas, aos tiros e à morte na Itália.

A Força Expedicionária Brasileira (FEB) somou à Segunda Guerra Mundial cerca de 25 mil homens dentre os 40 milhões mobilizados pelos Aliados. A mobilização brasileira ocorreu à base de diversos erros, não apenas logísticos como também basilares, principalmente no que tange a aparelhagem técnica militar (Meron, 2009). Em meio a tudo isso, elegendo a crônica jornalística como seu instrumento de trabalho, Rubem Braga externalizou valores referentes ao campo de sua profissão, concepções de mundo e técnicas, além, claro, de um "ser-estar" inerente ao jornalista naquele precário ambiente bélico. Logo, por meio de seus textos, pode-se analisar como se dá a representação peculiar de um ethos jornalístico em um período de restrições que vão da precariedade do front à tríplice censura pela qual passavam as crônicas (do exército brasileiro e do exército estadunidense, ambos ainda na Itália, e do Estado Novo, já no Brasil).

\section{A respeito do ethos discursivo}

Em termos históricos, Aristóteles trabalha de forma seminal a ideia de ethos ainda no século IV A.C, em seu livro A Retórica, no qual desenvolve paralelamente as concepções de pathos e de logos - conceitos que são os pilares da definição aristotélica da retórica - ou arte liberal da persuasão. Esses três conceitos, na perspectiva do filósofo grego, se articulam no escopo das qualidades consideradas necessárias por um bom orador: considera-se um discurso como efetivo quando o orador possui qualidade 


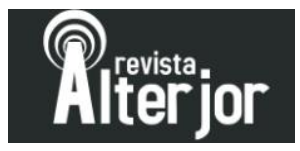

em sua argumentação (logos) e caráter condizente com seu discurso (ethos), além de conseguir captar de modo afetivo e sensível sua plateia (pathos). De acordo com Eggs (2005), todavia, o ethos emerge como massa amalgamadora dos demais conceitos trabalhados pela tradição da retórica aristotélica.

Embora as reflexões acerca da constituição da noção de ethos tenham se originado na Grécia antiga, e que haja conhecimento disso por meio das obras clássicas de Aristóteles, o conceito apenas ganha um espaço fecundo de discussão no pensamento moderno em meados do século XX. Conforme destaca Ruth Amossy (2005), resgatados pela pragmática moderna - campo da linguística em que se pesquisa a língua em seu contexto social -, os estudos sobre o ethos adquirem fôlego por meio do autor francês Oswald Ducrot, que se debruça a estudá-lo em interface com a enunciação e a semântica pragmática. Após as pesquisas de Ducrot, diversos outros autores passam a pensar a concepção de ethos em distintas interfaces. Emergem então estudos que correlacionam o ethos por meio da narratologia e dos trabalhos sobre a retórica; ou que buscam compreender o conceito na vertente dos Estudos Culturais.

Nesse ínterim, outras perspectivas de entendimento do conceito são desenvolvidas. Ruth Amossy (2005) propõe o entendimento do ethos como resultante de forças da pragmática moderna e da sociologia. Na vertente sociológica, em especial na perspectiva de Pierre Bourdieu (2008), o ethos - em interface com as noções de hexis e de eidos como desdobramentos do habitus - passa a ser compreendido como produto de trocas simbólicas, sendo moldado pela posição institucional na qual o enunciatário pertence e por tensionamentos intrínsecos aos diferentes campos sociais por ele percorridos. Posteriormente, Amossy (2005) destaca o conceito bourdieusiano de "força ilocutória", que pressupõe que a autoridade que emana do locutor não é propriamente de natureza linguística, mas fruto de um arcabouço institucional somado a ritos sociais. Segundo a autora, a despeito de a origem aristotélica do conceito remeter ao universo discursivo, o ethos não depende apenas deste âmbito para constituir-se. Nessa linha argumentativa, para que o ethos se legitime socialmente, ele deve se indexar em representações partilhadas, mantendo-se de alguma maneira associado a modelos culturais prévios para que possa encontrar um respaldo social (Amossy, 2005). 


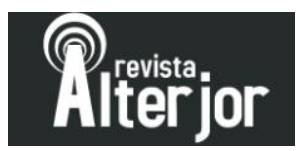

No terreno discursivo, ao menos desde 1980 o linguista francês Dominique Maingueneau tem se mostrado um dos maiores entusiastas no estudo do conceito de ethos. Embora o teórico francês defenda um entendimento distinto do ethos clássico na perspectiva aristotélica, buscando um diálogo com temáticas da modernidade, por outro lado situa-se conceitualmente em consonância com estudos anteriores para aportar em pontos em comum. Três aspectos são essenciais para compreender o ethos na obra de Maingueneau (2008). O primeiro diz respeito à própria noção discursiva do conceito, que reside intrinsecamente no discurso e não de modo exterior a ele. $\mathrm{O}$ segundo aspecto se vincula à compreensão de que o ethos constitui um processo mútuo de interação - e de influência - entre enunciador e enunciatário. O último aspecto refere-se à "noção fundamentalmente híbrida" do conceito, que se ancora em uma matriz sócio-discursiva; portanto, estabelece um diálogo permanente que não pode ser pensado senão no contexto em que foi realizado, ou seja, deve-se respeitar as demarcações sóciohistóricas e suas próprias características.

Nesse cenário, a reflexão apresentada pelo linguista francês remete ao ethos não de forma imóvel e estanque, mas como uma concepção que está a todo momento em trânsito, não apenas no discurso em si, mas operando sob os gestos, posturas e demais signos da vida cotidiana. De acordo com o linguista francês, a questão subjetiva pela qual a cena enunciativa é tomada por meio do discurso extrapola o estatuto que é concebido, não se restringindo à cena, mas “como uma 'voz' indissociável de um corpo enunciante historicamente especificado" (Maingueneau, 2008: 17). Finalmente, com o objetivo de sistematizar o processo, Maingueneau (2008: 18) ressalta que "o ethos de um discurso resulta da interação de diversos fatores". Tais fatores remetem, por sua vez, a três concepções - que, na perspectiva deste artigo, são também compreendidas como categorias analíticas: o ethos pré-discursivo; o ethos discursivo (ou ethos mostrado, junto a fragmentos de textos pelos quais o enunciador evoca sua própria enunciação); e o ethos dito (podendo ser materializado de modo direto ou indireto). $\mathrm{O}$ autor ainda reitera a frágil distinção entre as ideias de um ethos dito e de um ethos mostrado calcada apenas pelo ato da enunciação. Para Maingueneau (2008), ao final do processo, aporta- 


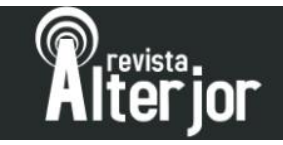

se sempre em um ethos efetivo, resultado das diversas interações mencionadas - como será explicitado na análise das crônicas de Rubem Braga.

\section{As crônicas de guerra de Rubem Braga e o "ser jornalístico"}

A crônica, curta em sua essência e muitas vezes leve em seu conteúdo, tem o seu nascimento no desenvolvimento dos grandes centros urbanos europeus, principalmente na Paris do século XIX, de onde se derivam os folhetins (Meyer, 1992). No Brasil, a crônica ganha grande destaque nos jornais com o passar dos anos, alcançando relevância e se consolidando como um formato de forte apelo nas décadas de 1930 e 1940. De acordo com Chaparro (2008), a crônica brasileira constitui-se na primeira metade do século XX como:

Uma espécie que traz para as páginas do jornal o talento literário de observadores atentos e argutos do cotidiano, capazes de descobrir no detalhe de um rosto, de uma lágrima, de um sorriso, de uma esquina vazia, de uma arquibancada cheia ou de um notívago perdido a representação dos encantos e desencantos da realidade mais complexa. (Chaparro, 2008: 131).

Nesse contexto de consolidação do formato no Brasil, a crônica de Rubem Braga, iniciada em meados dos anos 1930, desenvolve-se a partir de elementos caros à literatura e ao jornalismo, talhando a si própria no ritmo compassado da imprensa diária e remetendo à configuração de um ethos peculiar. Nos textos escritos por Braga como correspondente na Segunda Guerra Mundial, tais elementos se tornam evidentes. Aspectos como o enunciador-testemunha ou o cronista-repórter se entrecruzam e imprimem ao discurso uma marca dupla. Dessa maneira, tal como enunciado nas crônicas aqui selecionadas como recorte empírico, mostra-se possível observar ao mesmo passo um registro histórico importante como também um texto literáriojornalístico peculiar.

\section{Um espião, novembro 1944}

$\mathrm{Na}$ crônica, em um primeiro momento, o leitor é interpelado por elementos de verossimilhança que já aproximam o campo da literatura do campo jornalístico. Como 


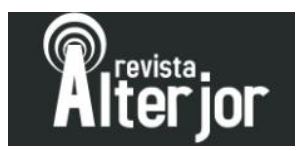

elementos primários, apresenta-se o local e a data logo após o título do texto. Tal destaque é repetido em todas as crônicas selecionadas e se constitui como elementoâncora de interface entre os campos aqui analisados. Um espião se inicia com o diálogo direto entre Rubem Braga e um italiano capturado que atuara como informante do exército alemão na Segunda Guerra Mundial.

- Quanto eles prometeram lhe pagar?

- Nove liras por mês

- Só?

- Não. Isso era o pagamento fixo. Sempre que eu fizesse um serviço bom, eles me dariam uma gratificação. Disseram que podiam dar até 50.000 liras de uma vez. Mas isso eu acho que não arranjaria. Só se levasse uma informação muito boa... (Braga, 2014: 65).

A crônica reconstitui o diálogo entre repórter e fonte com uso de travessão e de outros elementos discursivos caros à literatura. Dessa forma, constitui-se como base a cena englobante por meio de um discurso jornalístico que se dirige a cidadãos cariocas da década de 1940. Na sequência, ao refletir sobre o diálogo, Rubem Braga usa de aspas sobre a frase "uma informação muito boa"; e a partir dela desenvolve todo o segundo parágrafo sobre como tal informação poderia afetar os soldados brasileiros:

"Uma informação muito boa". Essas palavras, que esse belo rapaz de pouco mais de 20 anos está me dizendo com esse ar calmo e resignado do empregado que conta o seu ajuste com o patrão, querem dizer isto: uma informação capaz de causar a perda de um batalhão brasileiro inteiro, por exemplo. (Braga, 2014: 65).

Maingueneau (2013) aponta que o uso de aspas na análise discursiva não condiz propriamente com o discurso literal do interlocutor trazido à cena. De fato, Rubem Braga discorre sobre o espião italiano e vale-se de sua posição como correspondente para apresentar, com ironia, as (in)consequências da guerra com base no diálogo com o jovem italiano, que ao final descobre-se chamar Giulio. Embora Rubem Braga debrucese em um primeiro momento sobre este aspecto, outras linhas são utilizadas para discorrer sobre a vida do espião, suas motivações, suas relações com amigos e com sua mãe. $\mathrm{O}$ cronista ainda ressalta a inteligência e o conhecimento militar de Giulio antes 


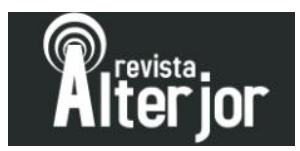

de, mais à frente, o interlocutor questionar se o repórter tomara nota de seu nome. Preocupado, o jovem agente é "tranquilizado" pelo repórter-cronista:

Seu nome não sairá no jornal, nem mesmo no meu distante jornal carioca. Seu nome não me interessa. De resto, é muito provável que ele apareça em muitos jornais, talvez junto com outros, numa notícia curta que dirá mais ou menos assim: "Condenados à morte como espiões, foram fuzilados os indivíduos: Fulano de tal, de tantos anos, de nacionalidade italiana; Sicrano de tal, de tantos anos". (Braga, 2014: $66)$.

No trecho, com astúcia, Rubem Braga recorre uma vez mais à modalização autonímica das aspas para enunciar prováveis manchetes em relação à morte do jovem espião. Dessa forma, o repórter se põe na posição de um enunciador que, a priori, reforça o ethos - dito e mostrado - jornalístico, mas logo em seguida ultrapassa a barreira do factual, propondo novos ângulos, seja por razões técnicas ou por razões pessoais e de preferências narrativas com ênfase em um ethos literário.

Ao fim da crônica, Rubem Braga retoma a questão do poder simbólico da imprensa quando aponta que Giulio implora para que não tenha seu nome citado no jornal: "Amanhã eu posso ir para os Estados Unidos ou para o Brasil, e se meu nome sair no jornal fica difícil arranjar um emprego" (Braga, 2014: 69). Logo em seguida Rubem Braga (2014: 69) explicita:

Despeço-me. A metade do que ele me disse e do que se apurou a seu respeito eu não contarei, de medo que a censura corte: o inimigo sabe muitas coisas a nosso respeito, mas há muita coisa que ele provavelmente não sabe que nós sabemos.

O tema da censura, assunto recorrente nos textos de Rubem Braga enquanto correspondente na guerra, aparece de forma explícita, como no caso em tela, ou de modo implícito, citando as dificuldades de se escrever do front sobre determinados assuntos. No excerto acima, além de mencionar a censura, o autor externaliza a questão da autocensura, prevendo justamente os assuntos que podem ser cortados e quais outros podem passar despercebidos pelas instâncias de cerceamento. Além disso, o autor faz menção a respeito da importância de certos conhecimentos em cenários de guerra. Embora a passagem sirva perfeitamente para o âmbito da Segunda Guerra Mundial, a 


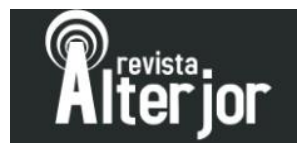

mesma promove um dialogismo com o cenário de exceção do Estado Novo varguista. Rubem Braga recorre, assim, tal como inscrito nas instâncias de seu ethos prédiscursivo, à sutileza da ambiguidade cara à imprensa nos períodos de autoritarismo.

\section{Luminárias, novembro 1944}

De maneira explícita ou de modo sutil camuflado em procedimentos técnicos, as crônicas de guerra de Rubem Braga valem-se de elementos caros ao jornalismo de sua época. É comum ao longo de todas as crônicas compiladas no livro - e, por conseguinte, nos textos do recorte empírico aqui analisado - um parágrafo introdutório, uma espécie de $l e a d^{4}$ apresentando o enfoque do texto. Em Luminárias não há exceção: "Um acampamento militar é um lugar bastante monótono para qualquer pessoa - e intolerável para um correspondente de guerra. Para começar, o que menos se tem no acampamento é notícia da guerra" (Braga, 2014: 46).

A partir do "lead literário", Rubem Braga desenvolve o fio condutor da crônica. Iniciando por sua enfática opinião sobre o ambiente da guerra, o escritor discorre sobre a falta de notícias de outras partes do conflito e ressalta que as únicas novidades que chegam ao front tratam de um "setor limitado de uma frente determinada". O anseio por notícias o faz refletir: “O que é um batalhão numa guerra?” (Braga, 2014: 46). Rubem Braga oferece aos enunciatários múltiplas cenografias que recaem em uma espécie de enlaçamento paradoxal; isto é, por um lado um o cenário de caos por se tratar de uma guerra, por outro um isolamento no deserto de notícias no qual paradoxalmente se habita em pleno confronto. Mais à frente, o autor chega à conclusão de que a ausência de contato com os grandes atos da guerra deve o conduzir a contar a história a partir de pequenas cenas: "o repórter que não tem notícias do mundo consola-se dando ao mundo notícias de um determinado setor" (Braga, 2014: 47).

Dessa forma, a construção discursiva de Rubem Braga destoa de uma estrutura textual clássica, na qual se parte da predominância do enunciador aliada a um fio condutor de base cronológica. Uma explicação para o desenvolvimento desse modus operandi recai nas próprias limitações estruturais de Rubem Braga em uma frente

\footnotetext{
${ }^{4}$ Lead jornalístico compreende as perguntas iniciais a qual o primeiro parágrafo do texto noticioso deve responder. Entre elas o "o que”, "quem", “quando", "como", "por que” e “onde”.
} 


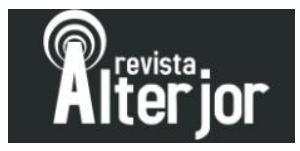

periférica da guerra, com acesso escasso às informações factuais da vanguarda, bem como com restrições oriundas da censura prévia das forças institucionais em jogo (a FEB, o exército estadunidense e o Estado Novo varguista) e com a precariedade da transmissão de seus textos via aérea. O potencial criativo do cronista encontra vazão, dessa forma, nos acontecimentos corriqueiros da frente de batalha e nos detalhes das vidas dos pracinhas, contraditoriamente, presentes naquele espaço-tempo de grande inflexão para a história mundial do século XX.

Em Luminárias, num movimento de inversão sobre os valores noticiosos clássicos, o escritor propõe um novo olhar para sua cobertura de guerra, ressaltando uma vez mais o seu papel de correspondente "via aérea". Ou seja, o mercado efervescente das notícias via telex, que se altera rapidamente com o breve passar do tempo e dos avanços nos campos de batalha, é descartado por Rubem Braga ao lançar mão alternativamente de suas crônicas e ao construir uma "história vista por baixo". Na crônica em crivo, o escritor se dispõe a uma reflexão sobre o próprio papel do repórter na guerra. Apresenta questões acerca dos valores noticiosos de determinados fatos, angulações noticiosas, além da ânsia dos leitores por notícias. Nesse bojo, o uso recorrente da narração em primeira pessoa reforça a pessoalidade do ethos dito e suas experiências frente aos eventos descritos, trazendo o enunciador ao primeiro plano e reforçando suas dúvidas e angústias - decalcando-se também na construção de um ethos mostrado.

Por fim, a crônica descreve um intenso fogo de artilharia cruzando o céu da cidade na qual ela é redigida.

Arranjamos um lugar para jantar, mas, quando à mesa, ouvimos o estrondo de centenas de tiros. Todos se erguem: fecham-se as janelas rapidamente. E quando pensamos que temos de nos meter em algum triste abrigo, é o contrário que nos acontece. Todos os que estão ali homens da Aviação e do Exército - saem à rua e ficam na calçada. (Braga, 2014: 48).

Compreende-se que o nome Luminárias remete metaforicamente à intensa luz produzida pelo fogo que rompe com o contraditório monótono da guerra na retaguarda e convida a todos da cidade a saírem às ruas para assistir ao céu iluminado pela artilharia militar. Sem deixar explícito, o autor desenha ao longo de toda a crônica uma analogia 


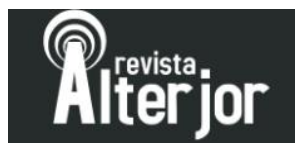

com o conceito de notícia. Aquele fato inaudito rompe não com a regularidade do batalhão de guerra, mas com a monotonia da cidade. Rubem Braga, portanto, desenvolve em Luminárias elementos de um ethos jornalístico - dito e mostrado - que reflete o próprio campo de atuação, ponderando sobre suas inúmeras possibilidades e limitações, tendo em seu vértice a precariedade de sua atuação na Segunda Guerra Mundial.

\section{Cartas, novembro 1944}

Muitas vozes compõem os textos de Rubem Braga e, por meio delas, o autor constantemente desenvolve suas crônicas. A crônica Cartas, datada de novembro de 1944, sobre as correspondências enviadas e recebidas pelos soldados brasileiros no front, situa-se nesse contexto de polifonia. Nesse sentido, a retomada de um aspecto teórico-conceitual na obra do escritor faz-se necessária. Batista (2012) analisa os textos de Braga sob um vértice literário calcado no registro do factual, transitando, portanto, entre as dualidades do autor:

O repórter [Rubem Braga] age de maneira a não transmitir a informação pura em si. Alguns acontecimentos são vivenciados por ele mesmo e, portanto, o narrador evidencia-se como testemunha, pois a experiência é sua. Outros episódios, que se tornam enredos das crônicas, são histórias ouvidas de terceiros; neste caso, o narradorrepórter em terceira pessoa aparece distanciado. (Batista, 2012: 15).

Sobre o cronista-repórter, Batista (2012) ressalta que tal característica em Rubem Braga se manifesta alimentada por lembranças pessoais e afetivas. Ao construir suas linhas (e entrelinhas), o escritor costuma rememorar sua infância em Cachoeiro de Itapemirim e a vida social no Rio de Janeiro e em outras paragens de suas andanças, recorrendo com desenvoltura ao uso de analogias e metáforas. Além disso, no caso de sua incursão na Itália com a FEB, Rubem Braga não se prende à descrição das ocorrências da guerra em seu sentido estrito, pois, como já mencionado, suas crônicas não eram telegrafadas, mas enviadas ao Brasil por avião, o que forçava o escritor a buscar novos modos de enunciar para além dos assuntos imediatos do front. Nas palavras do próprio cronista, "minha condição de correspondente via aérea me obriga aqui, mais uma vez, a reportar ao leitor a possíveis telegramas que tenham sido lidos por ele antes destas mal batidas linhas" (Braga, 1945: 97). 


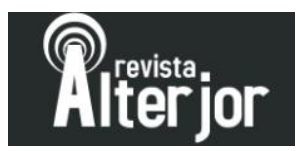

Uma vez mais, a categoria do cronista-repórter, aquele que enuncia por meio do diálogo, da subjetividade e dos afetos mostra-se basilar para o entendimento da forma de ser da crônica de Rubem Braga. O cronista-repórter, nesse ínterim, faz dos verbos e seus múltiplos tempos uma chave para desenvolver seu texto de forma a se aproximar dos enunciatários e, por conseguinte, estabelecer um "diálogo" - a relevância da miudeza, dos assuntos cotidianos e do ar de despreocupação, na definição de Antonio Candido (1992). A crônica Cartas, nesse escopo, encontra dialogismo também com outros textos construídos por Rubem Braga enquanto correspondente na guerra. A crônica Primeiras Impressões, por exemplo, que abre a odisseia do escritor na Itália, ilustra de forma certeira seu estilo:

Conversei ao acaso com um praça na frente, e calhou que era um rapaz de Barbacena. Chama-se Nélson Neves, e trabalhava na Central. Lembrando-me do tempo em que fazia reportagem política em Minas, e de uma eleição a que fui assistir em Barbacena, perguntei se o rapaz era do partido do Bias Fortes ou do Zezinho Bonifácio. Disse que ele e sua família eram do partido do Bias Fortes. Começou então a relembrar certos episódios da luta política local. Confessou que certos dias não tinha coragem de sair à rua em Barbacena, por causa da gente do Zezinho. Em compensação, quando Bias Fortes tomou conta da situação, a casa do Zezinho foi pichada. E Nélson teve este comentário raro: $-\mathrm{Ah}$, isso aqui, perto de Barbacena daquele tempo, é um sossego. (Braga, 2014: 36).

No excerto é possível perceber o modus operandi do cronista-repórter a partir dos próprios termos da conversa que Rubem Braga estabelece com o soldado natural de Barbacena. Com o transcorrer do diálogo, de essência coloquial, o cronista relembra o passado como repórter político no interior de Minas Gerais. Em tom prosaico, introduz um diálogo de conhecidos da mesma cidade. Até que, em um impulso de paroxismo, Braga põe-se a enunciar a comparação feita pelo soldado entre o tumultuado período de eleições em Barbacena e o confronto na Itália. Torna-se evidente, assim, de modo semelhante à crônica Cartas, a atuação de Rubem Braga na posição de cronista-repórter, na qual opta por privilegiar o tom afetivo do discurso do "outro" e a valoração da oralidade em meio às atrocidades da guerra.

Em Cartas, o enunciador Braga inicia o texto inserindo os enunciatários em uma cenografia que pressupõe proximidade: "Francis Hallawell - ou mais simplesmente, 


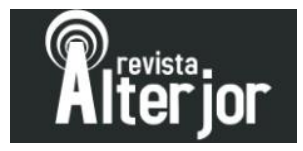

como toda a gente o chama aqui, o Chico da BBC - se deu ao trabalho de fazer umas estatísticas, e me disse que os expedicionários estão mandando muito mais telegramas do que recebendo" (Braga, 2014: 70). Identifica-se no trecho o que Maingueneau (2013) denomina de polifonia de vozes. Explicita-se que o dialogismo é com o jornalista britânico Francis Hallawell e ressalta-se o papel desempenhado pelo interlocutor no texto: introduzir o tema da crônica, as cartas que são mais enviadas do que recebidas pelos soldados. Em termos conceituais, Maingueneau (2013) situa a crônica como um gênero jornalístico "instável” - sem valer-se do sentido pejorativo da semântica justamente em razão da multiplicidade de vozes que mobiliza e por sua constante interferência na voz do enunciador principal - no caso, o próprio Rubem Braga. Desenvolvendo uma cenografia de proximidade com o interlocutor, tal como na menção ao apelido "Chico da BBC", Rubem Braga cria pontes de diálogo entre o trecho destacado, o título e o tema central da crônica: as cartas. De forma subsequente, o autor revela curiosidades acerca das correspondências, a exemplo dos "clichês" que são recorrentes nas cartas enviadas com saudações, congratulações, dentre outros.

Outrossim, em Cartas, Rubem Braga (2014: 72) faz uso de outro dialogismo, cuja identidade não é revelada, mas tem seu reforço por meio de travessão: “- Será possível? O Brasil tem mais de 40 milhões de habitantes e não há um só que se lembre de mim! Não há meio de me 'pagarem' carta". O trecho demonstra que além da polifonia de vozes, evoca-se no texto o discurso direto (DD), recriando-se a fala de um personagem. Como explica Maingueneau (2013: 182), "mesmo quando o DD relata falas consideradas como realmente proferidas, trata-se de apenas uma encenação visando criar um efeito de autenticidade, de uma espécie de imitação" - procedimento bastante caro ao ethos jornalístico. Dessa forma, a cenografia se potencializa no enlaçamento paradoxal relacionado ao convencimento da narração sobre o leitor. Em termos conceituais, o discurso, seja ele qual for, por sua própria manifestação, busca o convencimento por intermédio da cena de enunciação que o legitima; o discurso direto, nesse escopo, reafirma o ethos jornalístico mostrado.

Ao fim do texto, verifica-se outra característica recorrente nas crônicas de guerra de Rubem Braga: a forte interação com os enunciatários; neste caso, por meio de 


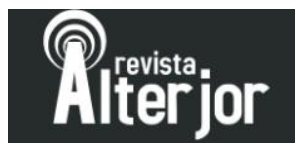

imperativos. Conclamando a população carioca a escrever para seus soldados na Itália, o escritor enfatiza: "Escrevam, telegrafem, meus senhores - e muito especialmente minhas senhoras" (Braga, 2014: 72). O trecho, além de sublinhar um diálogo direto com os enunciatários, incitando-os à ação, ainda revela implicitamente uma problemática sociocultural própria do período - uma questão de gênero. Os homens nos campos de batalha necessitariam, mais do que nunca, da atenção feminina.

\section{Imprensa de trincheira, dezembro 1944}

$\mathrm{Na}$ última crônica que compõe o recorte empírico deste estudo, Rubem Braga interpela mais uma vez a atenção dos enunciatários ao seu “lead literário", uma espécie de síntese do tema central da crônica. No texto, o escritor leva às páginas do Diário Carioca suas reflexões autorreferentes a respeito do papel da imprensa no desenrolar da Segunda Guerra Mundial, tal como se observa no parágrafo de abertura: "A imprensa não funciona apenas na retaguarda nestas guerras de hoje. Ela não cuida apenas do 'front interno': ataca o inimigo, saltando sobre suas linhas" (Braga, 2014: 77). Em seguida, Rubem Braga passa a erigir uma cenografia em tom explicativo. Todavia, ao tratar das dinâmicas da imprensa nas trincheiras e trazer ao debate o papel do jornalismo no conflito armado, alude-se às especificidades do período:

Trata-se de uma imprensa especial, frequentemente reduzida à condição de volantes, mas incluindo também verdadeiros jornais noticiosos e informativos. Os soldados alemães que lutam em nossa frente são cavalheiros bem informados do que vai pelo mundo. Os aliados os informam, dispondo para isso de jornais. (Braga, 2014: 77).

Ao ressaltar a existência de "verdadeiros jornais noticiosos e informativos", Rubem Braga enuncia de maneira implícita (ethos mostrado) um juízo referente ao modo de se fazer jornalismo - ainda que, paradoxalmente, seu estilo calcado em elementos da literatura o afaste do zelo pelo factual da imprensa informativa que despontava no período. A crônica, na sequência, é permeada pela perspectiva do repórter-cronista sobre o ofício do jornalista - em última instância, uma reflexão do autor sobre a deontologia da profissão naqueles idos e sobre seu papel na propaganda de guerra. Mais à frente, à esteira de refletir a respeito da contrainformação e da qualidade 


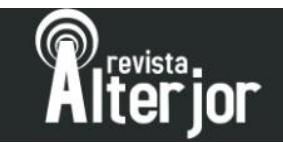

jornalística, Rubem Braga estabelece uma crítica à produção em língua portuguesa da imprensa de guerra alemã, ressaltando que os jornais "são feitos em um papel muito inferior ao destinado aos americanos, sem cores e sem ilustração”.

Ademais, em Imprensa de trincheira, o escritor faz uso da estratégia discursiva do intertítulo, recurso típico do jornalismo impresso - no caso em questão redigido em itálico: "Para os brasileiros". Trata-se, segundo Maingueneau (2013), de um modo de captar a atenção do enunciatário. A crônica ainda marca outra inflexão no contexto enunciado. Rubem Braga vale-se do texto para denunciar de modo implícito o racismo no interior da FEB: "O volante promete boa comida aos prisioneiros, sem distinção de nação e raça, e não apenas boa comida como consideração, pois lá 'não se desconsidera ninguém'. Nada, portanto, de racismo" (Braga, 2014: 78, grifos no original). A frase final, enfatizada pelo próprio enunciador, remete ao respeito à diversidade não apenas como uma estratégia discursiva genérica, mas constitui uma denúncia direta, porém implícita, dos casos de racismo registrados entre a alta patente da FEB. Em última instância, portanto, no seio da inventividade do cronista, constitui-se uma estratégia discursiva não explícita para driblar a censura e expor as fraturas da verossimilhança cara aos pracinhas brasileiros, o que adiciona complexidade ao ethos jornalístico efetivado pelo correspondente.

\section{Algumas considerações finais}

O modus operandi relacionado à constituição de um ethos jornalístico nas crônicas de guerra de Rubem Braga manifesta-se por meio da utilização de técnicas amparadas na profissão - a demarcação espaço-temporal de um "aqui-agora" e a abordagem das fontes, por exemplo - e das estratégias discursivas no escopo de seu estilo literário-jornalístico, tal como o uso efetivo de diálogos. Retoma-se, assim, já com suas respectivas respostas, as questões de fundo apresentadas no início deste artigo. Compreende-se que com base na técnica, Rubem Braga não apenas recria cenas, mas constitui cenografias que, por seu turno, legitimam as crônicas na aproximação entre jornalismo e literatura. Esse recurso enfatiza a relação entre jornalista e fonte, 


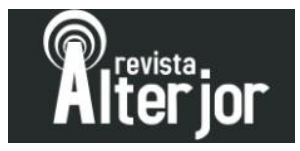

conotando uma sensação de efetividade dos procedimentos práticos do ofício: o repórter que vai a campo e não apenas apura, mas dialoga com seus interlocutores.

Nesse sentido, além da utilização do diálogo, a análise mostra que o uso da pessoalidade está imbricado no ethos discursivo do escritor. Suas memórias são recorrentes e atravessam os temas mobilizados. Desse modo, Rubem Braga interpela o leitor com recordações de sua infância, de sua juventude e de sua vida adulta no Rio de Janeiro e em outras paragens. Nota-se, assim, que quanto mais o cronista - por deliberação própria ou pelas circunstâncias do front - se afasta do trabalho de campo e da objetividade jornalística, mais próximo fica de suas memórias e, consequentemente, do campo literário, numa espécie de movimento pendular.

À esteira disso, uma característica transversal em relação ao ethos jornalístico expresso na narrativa de Rubem Braga se baseia na temporalidade impressa pelas marcas dêiticas. Tais marcas reforçam o grau de pessoalidade impresso nas crônicas, aumentando, por sua vez, as marcações discursivas de veracidade dos fatos, tendo em vista que o uso de tais expressões reforça o tempo e o lugar do narrador no curso da história. Nesse sentido, as estratégias discursivas explícita e implicitamente mobilizadas pelo cronista no reconhecimento das limitações materiais do front e das diferentes instâncias de cerceamento - os mecanismos linguísticos de contorno à censura e de publicização da autocensura - denotam uma dimensão ético-político de Rubem Braga própria de seu ethos pré-discursivo. São marcas, portanto, impregnadas no "ser-estar" do repórter-cronista - um Rubem Braga imbricado no tecido político brasileiro - que antecedem seu embarque no navio transatlântico no dia 22 de setembro de 1944 e que o acompanham na construção de cada texto.

Compreende-se, por fim, a escrita de Rubem Braga como singular no conjunto de elementos que caracterizam seu modo de fazer jornalismo. Sua pessoalidade, impressa no discurso autorreferente por sua visão simples, cotidiana e dialógica, contribui para que o ethos jornalístico seja representado na contramão da imagem de um repórter meramente calcado no discurso informativo - embora noticiar fatos fosse, num primeiro momento, um objetivo da incursão no front, diferentes circunstâncias, 


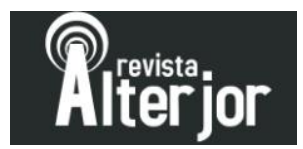

inclusive técnicas, levam Rubem Braga a investir em uma história da campanha da FEB "vista de baixo", não dependente da hegemonia das fontes oficiais.

O cronista busca, assim, novas formas de enunciar e rememora por meio delas suas histórias familiares, suas opiniões, seus desejos e seus sonhos. Publicadas nas páginas do jornal Diário Carioca entre os anos de 1944 e 1945, as crônicas de guerra de Rubem Braga, em suas múltiplas dimensões, antecipam elementos que foram comuns ao New Journalism antes mesmo do movimento literário-jornalístico estadunidense eclodir após o fim da Segunda Guerra Mundial pelas mãos de expoentes como Truman Capote, Gay Talese e Tom Wolfe. Nesse sentido, o escritor brasileiro constrói um ethos jornalístico efetivo - fruto do amálgama de um ethos pré-discursivo, de um ethos dito e de um ethos mostrado - por meio de características de um jornalismo calcado em aspectos da literatura concomitantemente à sua participação na narrativa, tensionando a todo momento seu próprio texto e contribuindo significativamente para a história da imprensa brasileira.

\section{Referências}

AMOSSY, Ruth. "O ethos na intersecção das disciplinas: retórica, pragmática, sociologia dos campos". In: AMOSSY, Ruth (Org.). Imagens de si no discurso: a construção do ethos. São Paulo: Contexto, 2005.

BATISTA, Geraldo José. "O cronista com a FEB na Itália: entre o factual e o literário". Anais do Simpósio Internacional Literatura, Crítica, Cultura. Universidade Federal de Juiz de Fora, 2012.

BRAGA, Rubem. Crônicas da Guerra na Itália. 7.ed. Rio de Janeiro. Record. 2014

BRAGA, Rubem. Com a FEB na Itália: crônicas. Rio de Janeiro: Zelio Valverde, 1945.

BOURDIEU, Pierre. A economia das trocas linguísticas: o que falar quer dizer. São Paulo: Editora da USP, 2008.

CANDIDO, Antonio. "A vida ao rés-do-chão". In: CANDIDO, Antonio (Org.). A Crônica: o gênero, sua fixação e suas transformações no Brasil. Campinas (SP), Rio de Janeiro: Editora da UNICAMP, Fundação Casa de Rui Barbosa, 1992.

CARVALHO, Marco Antônio de. Rubem Braga: um cigano fazendeiro do ar. 2. ed. São Paulo: Biblioteca Azul, 2013. 


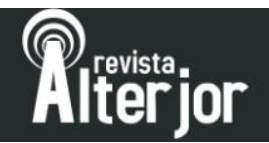

CHAPARRO, Manuel. Carlos. Sotaques d'aquém e d'além mar. Santarém: Jortejo, 1998.

EGGS, Ekkehard. "Ethos aristotélico, convicção e pragmática moderna”. In: AMOSSY, Ruth (Org.). Imagens de si no discurso: a construção do ethos. São Paulo: Contexto, 2005 .

MAINGUENEAU, Dominique. "A propósito do ethos". In: MOTTA, Ana Raquel; SALGADO, Luciana. Ethos discursivo. São Paulo: Contexto, 2008.

MAINGUENEAU, Dominique. Análise de textos de comunicação. São Paulo: Cortez, 2013.

MERON, Luciano Bastos. Memórias do front: relatos de guerra de veteranos da FEB. Dissertação (mestrado). Universidade Federal da Bahia, Salvador, 2009.

MEYER, Marlyse. "Voláteis e versáteis. De variedades e folhetins se fez a chronica". In: CANDIDO, Antonio (org.). A crônica: o gênero, sua fixação e suas transformações no Brasil. Campinas (SP), Rio de Janeiro: Editora da UNICAMP, Fundação Casa de Rui Barbosa, 1992. 